\title{
Left Populism and Platform Capitalism
}

\author{
Nick Dyer-Witheford
}

\author{
Faculty of Information \& Media Studies, University of Western Ontario, \\ ncdyerwi@uow.ca
}

\begin{abstract}
This paper contextualizes and analyses the policy proposals of new "left populisms" (Mouffe 2018) for the regulation and reform of the "platform capitalism" (Srnicek 2017) that increasingly organizes digital communication. The era of the 2008 crash and subsequent recession saw the emergence in North America and Europe of new left-wing electoral initiatives, either as new parties or fractions within older parties. These include, in the USA, Bernie Sanders and Alexandria Ocasio-Cortez Democrats; in the UK, Jeremy Corbyn's Labour Party; in Spain, Podemos; in Germany, Die Linke; in France, La France Insoumise. While many of these groupings might be described as socialist, or democratic socialist, they often also distinguish themselves from older socialist or social democratic formations; so, for lack of a better term, we call them left populisms. Left populisms are connected in contradictory ways to the appearance of platform capitalism, a corporate model exemplified by Google, Facebook, Apple, Amazon and Uber, deploying proprietorial software as a launch-point for user activities accessing commodified or advertising-driven goods and services. The rise of left populism correlates with the ascent of platform capitalists. Left populist parties emerged from the anti-austerity movements (Occupy in the USA, the Indignados in Spain, student campus occupations in the UK) organized with the help of social media platforms. However, it is also the failures and scandals of platform capitalism have been important to left populism. Edward Snowden's revelations of ubiquitous surveillance and the Facebook-Cambridge Analytica-Russian hacker imbroglio around the 2016 US election have fuelled a "techlash" against giant digital corporations that is now an important component of left populist sentiment. Drawing on policy documents, manifestos, speeches, position paper, this paper analyses the policy platforms in which left populist parties confront platform capitalism around issues of content regulation; concentration of ownership; the rights of digital workers; alternative ownership models; and proposals for a hightech driven transition to "postcapitalism" (Mason 2016). It considers the similarities and difference between and within left populist parties on these issues; the extent of their departure from neoliberal policies; and their differences, and occasional erratic similarities, with right-wing populisms, such as that of Trump. It then reviews critiques of left populism made from Marxist and ecological anti-capitalist positions, with particular reference to technological issues. The paper concludes with a summary of the opportunities and problems for a left wing "data populism" (Morozov 2016) in the current political conjuncture.
\end{abstract}

Keywords: left populism, platform capitalism, digital networks, capitalism, socialism, populism

\section{Introduction}

In the last decade, amidst economic crisis and recession, a wave of new left electoral parties or party fractions has appeared in Europe and North America. These include, in Europe, Spain's Podemos; Germany's Die Linke; France's La France Insoumise, and in the UK, Jeremy Corbyn's Labour Party. There are also parties that once might have been termed "left", for whom that designation now seems dubious, such as Greece's Syriza, and Italy's Five Star movement. In the United States, supporters of Bernie Sanders, Alexandria Ocasio-Cortez, and (by some reckonings) Elizabeth War- 
ren constitute a left resurgence within the Democratic Party. In Canada, Québec Solidaire adds to the roster. Some of these parties and party fractions (henceforward, for economy, "parties") self-describe as "socialist", or "democratic socialist". However, other of the new formations wish to distinguish themselves from older socialist or social democratic parties whose current conservatism they repudiate. Some observers speak of "movement parties against austerity "(Della Porta et al. 2017), but this formulation is both awkward and too broad, because different, right-wing tendencies have also emerged from the era of austerity. A more useful concept is Chantal Mouffe's (2018) "left populism", designating electoral parties claiming to represent the people against alien interests, interests that for right populisms are liberal elites or foreign migrants but in left populisms are corporate oligarchies.

Amongst the corporate oligarchies that left populisms oppose are those of "platform capitalism" (Srnicek 2017), the masters of the software and hardware infrastructures on which users rely to work, shop, sell, socialize and conduct ever-growing portions of everyday life. From such activities, proprietors of these "platforms" draw revenues via commodity sales, advertising, and data extraction. This business model, exemplified by Google, Facebook, Apple, Amazon and Uber, has spread from search energies and social media across the economy, driving the ascent of what are today some of global capitalism's most highly valued corporate giants. The idea of platform capitalism has been widely adopted by media and communication scholars. It has, however, been criticised for inadequately addressing the social conflicts surrounding the emergence of the new digital oligopolies (van Dorn 2017). This essay addresses that omission by examining left populist responses to platform capitalism, their proposals for its reform or supersession, and the problems and possibilities of such programs.

\section{From Street to State via Social Media}

Left populisms and platform capitalism are closely connected. Both emerged over the same period, from about 2004 to $2016^{1}$. The major connector is the Wall Street crash of $2007 / 2008$, and the decade-long recession in the Global North that followed. The economic meltdown propelled capital's search for a new growth sector, which it found in already nascent "platforms" (Srnicek 2017; Mosco 2017). Left populisms emerged as response to austerity, recession, debt, unemployment, precarity, and inequality, social problems that these platforms accentuated. But left populist parties were born from social movements that used capitalist platforms to protest these injustices. Many of such parties had origins in "occupy" or take the "square movements" ignited by the crash; Podemos in the Indignados' occupation of the Puerto del Sol in Madrid (Delclós 2015); Sanders' 2016 campaign for the Democratic presidential nomination in Occupy Wall Street (Gabbatt 2015; Stewart 2019); Momentum, the ginger group for Corbyn's ascent, from UK campus occupations of 2010-2011 (Earle 2018); Québec Solidaire

\footnotetext{
${ }^{1}$ On a purely impressionist basis, compare these chronologies. On the left populist side: Syriza was founded in 2004; Die Linke in 2007; M5S in 2009; Occupy movements were active from 2011 to 2014; Podemos was founded in 2014; Corbyn won Labour leadership, and Sanders ran his presidential nomination bid, in 2015; La France Insoumise was founded in 2018, and in that year Alexandria Ocasio-Cortez was elected to the US Congress; Sanders and Warren both bid for Democratic presidential nomination in 2019. On the platform capital side, Google launched its Initial Public Offering (IPO) in 2004, and Facebook did so in 2006 Apple sold its first iPhone in 2008; Twitter made its IPO in 2013; in 2017 Apple, Facebook, Amazon, Google, Microsoft occupied five spots amongst the top global corporations by market valuation; 2019 saw the IPOs of Uber, Lyft, and Pinterest.
} 
from French-Canada's "Maple Spring". Such movements famously organised via social media platforms. "Facebook revolutions" is undoubtedly a hyperbolic phrase, but one containing a grain of truth.

As the tide of occupations ebbed, some activists turned "from the streets to the state" (Gray 2018), and from "changing the world without taking power" (Holloway 2002) to taking parliamentary power. In doing so, they applied their familiarity with digital media to electoral politics. This dynamic is analysed by Paolo Gerbuado (2019) in his The Digital Party, which examines both the strengths and weaknesses of such organising. Gerbaudo acknowledges the speed, scope and precision of digital campaigns, and its obvious appeal to youth completely familiarised with networked environments. But he also charts unexpected consequences, such as a tendency to polarise party structures between what he terms "hyper-leaders", whose charismatic image is built around carefully cultivated online presence, and "super-bases" of followers prone to rapid networked endorsements of their initiatives.

This paper does not, however, deal further with these tactical campaigning and organisational uses of digital media by left populist parties. Rather, it focuses on the strategic issue of the programs left populists have proposed for the reform or supersession of platform capitalism. For although left populisms organise via digital platforms, their rise coincides with great scandals about such platforms: Edward Snowden's surveillance revelations; the Facebook-Cambridge Analytica-"Russiagate" imbroglio; multiplying issues of hate speech, network toxicity and privacy abuse. Further, for millennial youth, the employment practices of Uber, Mechanical Turk, Task Rabbit, Deliveroo and CloudFlower typify the worst of a precarious gig-economy. All this has informed a mounting "techlash" (Foroohar 2018) underway since 2017. In this context, what Evgeny Morozov (2016) terms "data populism" - a critique of the oligopolistic powers of digital giants - became an important part of left populism.

These proposals for reforming or even dismantling platform capitalism have many strands. Some issues are specific to particular nations. For example, in the United States, Sanders and his supporters were active in protests against the Trump administration's 2017 revocation of "net neutrality" - the principle that Internet service providers (ISPs) treat all data equally and not speed or slow it for profit (Coldewey 2018). The fight for net neutrality was in the US a major cause, and a bellwether for other struggles over digital policy. But while left populists in Europe and Canada are concerned about the US precedent (Orsini 2017), no similar attack on net neutrality has yet been mounted in these regions, so the issue does not have the same salience.

Yet despite such differences, left populists have common proposals about platform capitalism. These commonalities can be tracked through party programs; policy statements; position papers; and speeches and books by party leaders, members, advisors and sympathisers. Drawing on such sources, I outline five themes:

a) calls for the regulation of Internet speech and privacy (Section 3);

b) "trust-busting" legislation to break up concentrations of ownership (Section 4);

c) regulation of gig economy working conditions (Section 5);

d) forms of alternative ownership of digital resources, including nationalisation, municipal digitalism, open-source institutions, and platform cooperatives (Section 6)

e) plans for a digitally-driven transition to "postcapitalism" (Mason 2015; Section 7).

\section{Internet Speech and Digital Surveillance}

Issues of Internet speech regulation and privacy protection are the least distinctive area of left populist policy proposals, but only because these concerns have suddenly become widespread. Since 2016 there has been a surge of concern across the political 
spectrum over hate speech and also at least ostensible expressions of outrage at the scope of commercial privacy invasion. In Europe, such concerns are now widely adopted by the political centre. In the US, Mark Zuckerberg himself called for government rules for social media content as the price of preserving his private empire (BBC 2019). Here left populism has contributed to "mainstreaming" of policy ideas unthinkable only a few years ago, but now conventional wisdom.

Left populist perspectives on speech regulation do however have inflections that separate them from centrist and conservative positions, largely to do with concerns about the national security state. While generally supporting regulation of hate speech and other toxic Internet content, left populist parties have criticised reliance on corporate-run semi-automated screening systems, and the danger of blacklisting all forms of dissent. Thus in 2009, Die Linke opposed Germany's "access" legislation for blocking content such as child pornography on the grounds that "a largely uncontrolled technical censorship infrastructure is in principle incompatible with fundamental rights" (Feilner 2009). In Spain, Podemos' leader Pablo Iglesias denounced prosecutions of artistic works, including online content and retweeted jokes, for alleged "glorification of terrorism" under the conservative governments notorious "gag law" (López-Terra 2017; Jones 2018)

Left populists have also highlighted platform capital's collaboration with the unconstrained surveillance projects of state intelligence agencies and police forces. In the US, Sanders opposed the Patriot Act, warrantless wiretapping and overly broad government surveillance as blatant overreaches of government power, and has recently has denounced the police use of facial recognition technologies (Lutz 2019). When Jeremy Corbyn (2016) launched a "people's charter of digital liberties", it pledged to protect British citizens from "unwarranted snooping on their online activities by the security services". Such concerns are particularly acute for left populist parties because some, of them, such as Podemos and the Labour Party, have themselves been subject to state surveillance (Nikandrov 2015; Evans 2017). However, these parties have also sometimes themselves been criticised by surveillance activists for compliance with state authorities around digital monitoring of terrorist or separatist threats (Ball 2016; López 2019).

\section{Concentration of Ownership}

Digital trust-busting - breaking up Google, Facebook and other digital giants - is a natural issue for left wing parties. Leaders such as Sanders and Corbyn regularly denounce monopolistic capital, including that in the media and communication sector. It is, however, another sign of recent "techlash" that left populist parties are today far from alone on this question. Anti-trust activities have returned to the policy repertoire of even centrist institutions. Since 2016, the European Union has fined giant US platform capitalists for anti-competitive practices, such as Google's abuses in the mobile phone, shopping-comparison and online-advertising sectors, Facebook's melding of personal data gathered from its various subsidiaries, and Apple's tax evasions (StevisGridneff 2019) - even if these multibillion penalties are minor relative to the wealth of their targets, and payment indefinitely delayed by litigation.

However, the issue takes on a more serious complexion in the USA, where legislation could, hypothetically, actually divest Alphabet/Google or Facebook of corporate holdings. The argument for such action has historical precedent. If "data is the new oil", why not apply the same logic that made Rockefeller's empire the target of early twentieth century trust-busting? Despite Sanders' long anti-monopoly record, it is Elizabeth Warren (2019) who has made digital anti-trust a central policy plank of 
her campaigns and indeed one of her central claims to being counted as a "left populist". Her proposal to structurally separate the corporate operation of a digital platform from sale of its own products (for companies with over $\$ 25$ billion in annual global revenue) updates the classic regulatory principle of division between "carriage" and "content" (Dayen 2019). It explicitly has Amazon Marketplace, Google's ad exchange, and Google Search in its sights. Warren's proposal is reinforced by promises to investigate and reverse anti-competitive mergers and acquisitions in the digital domain, naming Amazon, Google, and Facebook as probable targets (Warren 2019; Dayen2019). Sanders has endorsed the idea of breaking up Facebook.

The anti-trust attack on the "bigness" of Big Tech has become a new horizon for progressive activism in the US. One should not, however, overstate its radicalism. As Warren herself makes clear, anti-trust is not inherently anti-capitalist; rather, it protects the so-called free-market against its self-destructive tendencies. The breakup of the regulated telecommunication monopoly of AT\&T can be regarded as a founding act of neoliberalism (Lüthje 1993). Indeed, on anti-trust, left populism overlaps with right populism. Trump has made forays into this area, posing as a tribune of the people in his highly personalized feud with Jeff Bezos' Amazon. His administration is now taking a more systematic approach to the issue, with Department of Justice investigations into anti-competitive platform practices recently announced (The Economist 2019a). Ironically, "legacy" media moguls such as Rupert Murdoch support the breakup of their digital competitors (Scola and McGill 2019). Despite left populism's embrace of "antitrust", there can be no assumption its outcomes would be democratising. All depends on what alternatives might be available to fill the space created by diminishing the oligopolies of platform capitalism. I turn to this question in a moment, but first we should look at the related issues of digital labour conditions.

\section{Gig Worker Rights}

Left populist parties are virtually unanimous in their critique of the low wages, precarity and lack of benefits suffered those who work for platform capitalists. Amazon fulfilment centres, with their reliance on temporary workers and zero-hour contracts, relentless digital monitoring, mental and physical stressing of employees, and poor health and safety conditions epitomise the problem. Left populists also target so-called "lean platforms" (Srnicek 2017) such as those of Uber, Lyft, and Deliveroo that rely on algorithmic management to coordinate workers using their personal equipment (cars or bikes), and classifying them as "self-employed" agents to avoid responsibility for training, safety provisions, health insurance, holidays and other benefits.

In this regard, La France Insoumise (LFI), a party whose appearance was directly related to protests against the liberalising of France's labour laws under Sarkozy and Macron, is exemplary. LFI uses the term "Uberisation" to identify "a breakdown of work structures" that is "due to the emergence of a model organized around digital platforms". It declares Uberisation a "social regression" characterised by "wild deregulation of professions and sectors" and "fraudulent and widespread circumvention of fiscal and social rules". Uberisation "causes workers' rights to disappear [...] through massive recourse to self-entrepreneurship" producing "an unprecedented deterioration in working conditions" and accumulating profits" while "squeezing wages and social rights" (LFI 2017). LFl's leader Jean-Luc Mélenchon has also argued that "Uberisation" is gender-coded and especially injurious to women because "Uber's world is that a selfemployed worker without rights, who thinks he's smart as long as he's healthy and has no children" (Durand and Goldberger 2018). 
LFI therefore explicitly situates itself on the side of recent labour protests in France- taxi drivers protesting Uber, bicycle courier collectives formed after the sudden closure of the Tok TokTokTake and Eat Easy - and also of worker movements in the US and UK fighting to "reclaim their pseudo-independence and combat over-exploitation". It proposes that precarious and so-called self-employed workers be given full access to the" general social security scheme"; "every worker performing his or her work in a situation of economic dependence [...] must be presumed to be an employee, and thus enjoy the rights attached to it". LFI also proposes that platform capitalists be subject to "approval procedure that will make it possible to verify that they meet the social, fiscal and regulatory obligations in force" (LFI 2017).

Similar statements and policies can be found from almost all left populist parties. Die Linke's 2011 platform declares the party against "replacement of the regular workforce by temporary agency work or bogus self-employment"; a later "digital agenda" advocates redistributing the benefits of advanced digitalisation, including a 30-hour working week, a basic income, and at least two sabbaticals during every working lifetime (Offerman 2017). UK Labour Party leader Jeremy Corbyn accuses "unscrupulous bosses" of using technology to undermine workers' rights; declares that the gig economy, depicted as "modern and dynamic", actually denies "both employees and customers basic protections" and harms workers' mental health; and urges young people to join a trade union to protect their rights. A Labour government would, he says, make it easier for unions to go on strike and extend full employee rights to all workers in the gig economy - such as sick pay, parental leave and protection against unfair dismissal. (BBC 2017). In the US, Bernie Sanders in 2018 drafted a Stop Bad Employers by Zeroing Out Subsidies (Stop BEZOS) Act, a proposal for a tax on large corporations equal to the federal benefits their low-wage employees would have to claim to make ends meet (Heater 2018). His recent Workplace Democracy plan has promised the abolition of the "independent contractor" status of workers in companies such as Uber and Lyft. Both Sanders and Warren have supported the struggle for California's historic Bill AB 5, an important step in this direction (Corbett 2019).

\section{Alternative Ownership}

Left populist parties have many ideas about diversifying control of digital platforms, part of their wider reconsiderations of what social ownership of the means of production might mean today (Beckett 2019). An important statement of this approach is the 2017 study of "Alternative Ownership" commissioned by the UK Labour Party. This envisages reviving and revising traditional models of industry nationalisation, adding higher levels of transparency and accountability to public-sector ownership; fostering economic activity by municipalities and locally-led social enterprises; encouraging worker's co-operatives and other employee ownership plans. This is a general plan, not one specific to digital platforms. But all of these alternative ownership approaches - and some more beside - have application to platform capitalism, and have been taken up, with varying inflections and intensities, by other left populist parties.

\section{(i) Public Sector Platforms:}

The Alternative Ownership paper per se actually has little to say about digital industries, though it cites the UK postal services, alongside railways and the energy sector, as privatised services to be re-nationalised under its new model. But Labour leadership speeches, policy statements and think tank pieces fill out the picture. A "British Digital Corporation" (BDC), a sister to the BBC, would host non-profit services rivalling those 
of digital corporations, including a Facebook alternative (Jones 2018; Lunden 2018; Watson 2019). Other public service applications promised in the Labour Party's (2016) Digital Democracy Manifesto include a guarantee to "deliver high speed broadband and mobile connectivity for every household, company and organisation in Britain from the inner city neighbourhoods to the remotest rural community"; a free-to-use on-line hub of learning resources for the National Education Service; an "open-knowledge" portal where "the findings of all state-funded research to be made available without charge" and enabling online voting, and even public meetings, in elections. In a similar vein, La France Insoumise pledges to oppose corporate platforms with "public platforms of general Interest" dealing with both "physical services (public transport, local product distribution networks, etc.) and immaterial services (access to law, transparency of data, etc.)," and ensuring that "the value created by an ecosystem is paid back to society, not captured in financial form" (LFI 2017).

The most dramatic initiative on public sector initiatives from a left populist party to date is, however, the announcement by the Labour Party in its 2019 election Manifesto that it would provide full fibre broadband service to everyone in Britain by 2030 (Labour Party 2019, 51). This "British Broadband" service would be created by nationalising the digital network arm of the private company BT (British Telecom), compensating shareholders to the tune of about $\$ 15$ billion (Fildes and Pickard 2019); the costs for operating the new network would be paid for by "taxation of multinationals, including tech giants" (Labour Party 2019, 51). The pledge elicited an alarmed counterattack by the Conservative Party, the tabloid press and BT spokespeople, all claiming it underestimated costs of the project. At the time this article was finalised, the UK election campaign was still underway.

\section{(ii) Digital Municipalism:}

Progressive digital municipalisms has been pursued especially vigorously in Spain by Podemos and its city-level political allies, such as Barcelona en Comu and Más Madrid (Baird and Junque 2019; Romanos and Sádaba 2016). In Barcelona, during the mayoralty of Ada Colau, the city's chief technology officer, Francesca Bria (2018) and her colleagues developed "a new social contract for the digital age". Data gathered from services such as transportation would be a publicly owned and protected asset, used for urban planning purposes; a TOR-encrypted whistle-blower tool shielded public workers denouncing corruption; urban 3D-printing maker labs were set up; and a special online platform enabled citizens to participate in civic policy making (Bria 2018; Barcelona Ciutat Digital 2019).

In Madrid, under the mayor Manuela Carmena and her Ahora Madrid party, Spain's capital experimented with similar initiatives, including the use of the Decide open source platform for participatory budgeting, citizen policy proposals and consultation processes (DeJohn 2017). These metropolitan projects supported a network of smaller municipal initiatives in Spain, and internationally. Not all these efforts have been successful, and recent municipal elections saw setbacks for left parties in Barcelona and Madrid. Recent assessments of prospects for a left digital urbanism strike a soberer tone than earlier utopian visions (Morozov and Bria 2018). Nonetheless, these experiments have provided practical laboratories for the digital policies of left populism, and are critically important in suggesting alternatives to corporate led "smart city" plans, such as Google/Alphabet's infamous "Quayside" appropriation of Toronto's waterfront. 


\section{(iii) Open Source Institutions:}

Many left populist manifestos mention the progressive potential of "open source" software and hardware. For example, soon after its formation Die Linke took a pro-open source stance (Feilner 2009), and just before the 2017 German federal elections published a document titled "10 Points For a Digital Agenda" (Kipping et al. 2017). Its authors, three of whom previously worked for the Pirate Party, rearticulated the aspirations of the Free and Open Source Software (FOSS) movement for "digital cooperation, collaboration, sharing and re-use" within the framework of a socialist electoral project (Offerman 2017). The realisation of FOSS ideals, they said, depends on an institutional framework that not only provide the necessary legal protections but also encourage widespread adoption of open source and open standards software. Without such an institutional context, big data and machine learning and other computing innovations threaten the emergence of a digital feudalism. However, a left government could legislate the conditions in which cultural products and scientific knowledge would become free and available to all as open data. In contrast with Germany's "Industry 4.0" policy of intense automation, they posit the creation of "Social State 4.0". All public networks would be based on open-source infrastructures; internet access should be free; all software used in political processes would be open source. "We want," the manifesto says "to uninstall the neoliberal version of platform capitalism and create a new drive system" (Kipping et al. 2017).

\section{(iv) Platform Cooperatives \& Inclusive Ownership:}

An important strand in left populist ownership plans is the digital extension of left traditions of Co-operativism. Platform co-operatives are businesses based on computing platforms, but owned and governed workers and users. Many such projects currently exist, though generally on a small scale (Scholz and Schneider 2017). The concept is widely supported by left populist parties as an alternative to the exploitative path of the gig economy. It has been embraced La France Insoumise, supported in the progressive municipalism of Podemos allies, and celebrated by Corbyn (2017): "imagine an Uber run co-operatively by the drivers, collectively controlling their futures, agreeing their own pay and conditions, with profits shared or re-invested".

The Co-operative Party, an affiliate of the Labour Party, proposes large scale digital systems to assist workers and consumer cooperatives, including platform cooperatives (Lawrence et al. 2017). Platform Co-operativism has been criticised for underestimating the difficulties small enterprises confront in face of the massive network-effect advantages enjoyed by established platform capitalists (Srnicek 2017), condemning worker- and user- owned alternatives to the "dwarfish forms" Marx saw as the fate of all co-operatives within capitalism.

However, left populist plans include state support for cooperatives, including platform cooperatives, by, for example, financing through special investment banks. How far this would be sufficient to give platform co-operatives a fighting chance to compete with the Ubers and Googles is, to say the least, uncertain. However, it is also important to note that left populist programmes also include methods of advancing worker ownership that do not depend on the co-operative form but aim at similar goals. These include the idea of "Inclusive Ownership Funds" (IOF) by which a small percentage of companies' shares would be regularly transferred to workers up to a set cap (say 10\%), and idea with roots in postwar Sweden's labour-led "Meidner Plan" (Gowan and Viktorsson 2017). The funds would, in many firms, soon make the workers the largest 
single shareholder, able to elect their own trustees and directly influence company decisions. This idea has been most developed by the UK Labour Party, but was also recently adopted by Sanders (Blackburn 2018; Gowan 2018; Bruenig 2019b). Such plans - a variant of an earlier tradition of "fund socialism" (Bruenig 2019a) - are not specific to platform enterprises, and lack some of the DIY appeal of platform cooperatives, but do offer a gradual route to somewhat collectivizing ownership of behemoths of platform capitalism.

\section{Postcapitalism}

While anti-trust legislation, gig worker protections and alternative ownership plans would be important reforms, they are not the most audacious left populist ideas for dealing with platform capitalism. For these, we have look to a group of left intellectuals broadly in the orbit of Corbyn's Labour Part.; Nick Srnicek, not only an originator of the term "platform capitalism" but also co-author with Alex Williams Inventing the Future (Srnicek and Williams 2015); journalist Paul Mason, advocate for Postcapitalism (Mason 2015); and Aaron Bastani (2019), proponent of Fully Automated Luxury Communism. These thinkers are united by the idea of a left populist politics with a programme based on the rapid development of a high-tech economy which, they believe, opens a path to a society of abundance in many respects beyond capitalism.

The major process enabling this transition would be the erosion of the need for wage labour by artificial intelligence (AI), robotics and other advanced forms of automation. Paid work would be progressively replaced by either Universal Basic Income (UBI) (Srnicek and Williams 2015; Mason 2015), or a comprehensive range of Universal Basic Services such as health care, transportation, housing, education (Bastani 2019). To this Mason and Bastani adds the idea that a digital economy will inevitably generate more and more free goods, as point and click reproduction reduces marginal costs to zero. As the freely available goods include will include tools for communal planning, the possibility for a society that is both freed of wage labour and increasingly capable of democratized decisions, and hence substantially "beyond capitalism" will, it is claimed, emerge.

This "left accelerationist" (Williams and Srnicek 2013) vision of a postcapitalism attained by speeding up high-technology has classic Marxist roots in the idea that capitalism will be destroyed by the tension between the force and relations of production, and also in the famous "Fragment on Machines" in Marx's Grundrisse, which appears to predict dissolution of the wage form by automation. It is also in a way the digital-era successor to Lenin's enthusiasm for the assembly line and definition of communism as "the soviets plus electricity" - with one important difference: it dispenses with the messy business of revolution, substituting an evolutionary, tech-driven path to postcapitalism.

"AI plus UBI (or UBS)" [Artifical Intelligence; Universal Basic Income; Universal Basic Services] has become a mantra for some strands of left populisms. It has a complex relation to left populism's other major societal vision, that of a "Green New Deal" responding to climate emergency, an idea most energetically advocated in the US by Alexandria Ocasio-Cortez, but echoed in the UK Labour Party, La France Insoumise and other left populist formations. Fully Automated Luxury Communism (FALC) and a Green New Deal (GND) can be seen as compatible, if the latter is interpreted solely as an eco-modernising project, dependent entirely on developing large scale solar, wind and other renewable energy systems. However, there is an obvious tension between the "automation now", "post-work version" of FALC and the New Green Deal emphasis on "green jobs". And the potential contradictions between the two increase sharply if a 
GND is understood as including any de-growth component that would curb aggregate production and consumption, undercutting the promise of abundance integral to FALC.

It thus cannot be taken for granted that an effective NGD is fully compatible with either the "automation" or the "luxury" of Fully Automated Luxury Communism. In regard to digital networks, many eco-modernist proposals for high-technology solutions to global explicitly rely on big data monitoring of energy consumption and use (Bratton 2019), and could be expected to entail state-led surveillance, social media nudging and admonition aimed at shaping such behaviour. It is, again, uncertain how far such an element of a GND would be compatible with the commons, privacy protection and freedom from surveillance made in the "new data deal" (Bria 2018) that left populist parties also advance.

\section{Conclusion: Problems and Possibilities}

Left populism presents an amalgam of policies to change platform capitalism. Some are modest neo-social democratic steps (Watkins 2016), others more ambitious. This mix is, as we will discuss, problematic. But it nevertheless marks a significant incursion on neoliberal "common sense", opening a window to ideas of public ownership of technologies and network governance in ways not seen since 1970s. This shift in the wind has been registered by opponents of the left. The Economist (2019b) reports on the rise of "millennial socialism" with alarmed condescension; in the USA, Republican attacks on figures such as Alessandria Octavia Cortes manifest both confidence "socialism" can't win - so should be talked up - and fears it might - so must be run down.

Left populism is however also controversial on the left. Mouffe is a declared "postMarxist" (Laclau and Mouffe 1985). The turn to a parliamentary strategy and a disavowal of a specifically class politics characteristic of left populist parties has led some Marxists to declare it "pseudo-socialist" (López 2019). Many see populism as almost inherently right-wing (Dean 2017; Revelli 2019). Others, while critical of post-Marxism, nonetheless believe a left populism drawing on the concept of "the people" - as in "the popular front", or "the people united shall never be defeated" - has communist and socialist potential (Rancière 2013; Sotiris 2019). This debate is joined and cross-cut by autonomists, communisers, anarchists and horizontalists of all stripes, often opposed to any party form or parliamentary strategy. Bearing these entangled discussions in mind, I conclude with a brief review of three criticisms of left populist strategies towards platform capitalism.

First, and most pragmatically, left populist ideas are still a long way from the corridors of state power. So far, no left populist party has achieved a national electoral victory, other than Syriza, which in 2014 marked its success by abdicating its antiausterity mandate, and Italy's Five Star party, which promptly entered a disastrous coalition with the far right. Since then the torch passed to first to Podemos, now in decline, then to the British Labour Party, currently mired in Brexit problems, and to the US, where at the time of writing, Sanders and Warren, though important contenders in the Democrat's nomination race for the presidential election of 2020 are still widely considered unlikely to win. Parties formed in the period of acute crisis following the Wall Street crash have faced a more difficult terrain during the subsequent slow and ambivalent economic recovery - and will face another changed situation in any future recession.

The issues of the digital industry and network policy discussed here are probably by no means the most significant in determining left populist electoral success or failure, which may hinge far more on health care, education, debt, trade and immigration. 
In particular, it is unclear how much traction long-view promises of a high-tech postcapitalism have with households immediately concerned about low pay-cheques, skyrocketing child-care and education costs and diminishing welfare rates. ${ }^{2}$

Second, were a Corbyn or a Sanders to win electoral victory, as David Broder (2019) observes, "their difficulties would only begin". The left turn "from the street to the state" since Occupy has reignited a series of debates about the problems of any electoral transition to socialism that for Marxists go back to the arguments of Lenin, Bernstein, Kautsky and Luxemberg at the start of the $20^{\text {th }}$ century to those of Poultantzas and Miliband at is mid points. As Broder remarks, there is a "dismal record" of supposedly socialist governments which, rather than reforming or abolishing capitalism, were instead themselves "reformed" to become "mere administrators of the existing system". This is often explained in terms of the class backgrounds of politicians and civil servants, but ultimately the problem is structural. In capitalism, state revenues depend on national capital and ensuring that capital's continued profitability is a compulsion; without it "the state itself would collapse" (Bolton and Pitts 2018, 143). For a left populist government to quietly erode capitalism from within, without bringing the house down on its own head in a crisis that would require a far more revolutionary response, would be extremely difficult. It is not hard to imagine, for example the resources that a Google or Facebook could throw against policies aimed at their expropriation. This is point about which the most lucid supporters of left populists (such as Broder) are very well aware, but to which they do not necessarily have a good answer (see also Sunkara 2019; Blanc 2019).

The third critique, however, is that despite its apparent radicalism, left populism has already, prior to election, conceptually made deep pre-emptive compromises with capitalism. Left populist parties generally assume and advocates a social path of high technology, high productivity modernity. And even though these policies are termed "postcapitalist", they are sometimes, virtually in the same breath, advocated both as leading "beyond the market" and as a way capitalism might "escape" from its current economic stagnation (Mason 2015, loc. 144). Left "accelerationist" ideas of a post-work society based on state-supported "fourth industrial revolution" development, with a UBI to pacify surplus populations, could well be enabler of, rather than alternative to, large scale capitalist Al development (Dyer Witheford, Steinhoff and Kjosen 2019). Ecosocialists might also suggest that the idea that human emancipation is identical with the advance of a high-production, high-technological networked society is precisely what is thrown into question by global heating and other environmental-crises, and by the critique from the South of extractivism and low-cost microwork. There is a real question as to how far political platforms for "socialism with an iPad" (to use a phrase of Corbyn's shadow chancellor, John McDonnell) are adequate to the scale of today's planetary crisis (Davey 2016).

In raising these points, I by no means propose a blanket rejection of left populism. On the contrary, I think it is an important, substantive project. I do want, however, to suggest it be understood as a moment in a long arc of post-crash politics. Left populist parties were born out of struggles, as a response to the defeat of occupy movements. Their development will depend on further struggles, both within the broad left, and against its opponents. Any electoral left populist success would probably unleash pan-

${ }^{2}$ Adam Greenfield $(2017,109-110)$ reports a cautionary episode in which a well-intended attempt to establish as 3-D printing lab in an impoverished area of Barcelona on the site of a former community food bank was angrily resisted by residents! 
icked reactions, violent in both overt and subtle ways, from the most conservative sections of capital and the neo-fascist right ${ }^{3}$. It would also catalyse conflicts within the left, between those who wish to contain electoral victory within a first world social democratic frame, and those seeking yet more equalitarian and ecologically viable outcomes. In this sequence, the electoral bot and party blog are followed by the return of the red hack and the mobile phone coordinated riot. Seeing left populisms not as an endpoint of struggles, but as a relay or node in an ongoing cycle of conflicts that has flowed from the street to the state and will likely flow back again, is perhaps the most productive and realistic way to understand these parties and their relation to platform capitalism.

\section{References}

All URLs accessed on November 29, 2019.

Baird, Kate and Marta Junque, eds. 2019. Fearless Cities: A Guide to the Global Municipalist Movement. New York: New Internationalist.

Ball, James. 2016. Jeremy Corbyn Still Supports Theresa May's Surveillance Law. BuzzFeed News, 30 August. https://www.buzzfeed.com/jamesball/jeremy-corbyn-still-supportssnoopers-charter-despite-launch

Barcelona Ciutat Digital. 2019. Putting Technology at the Service of People. https://ajuntament.barcelona.cat/digital/sites/default/files/pla barcelona digital city in.pdf @BCNdigital

Bastani, Aaron. 2019. Fully Automated Luxury Communism. London: Verso.

Beckett, Andy. 2019. The New Left Economics: How a Network of Thinkers is Transforming Capitalism. The Guardian, 25 June 2019. https://www.theguardian.com/news/2019/jun/25/the-new-left-economics-how-a-network-of-thinkers-is-transforming-capitalism

BBC News. 2019. Mark Zuckerberg Asks Governments to Help Control Internet Content. BBC News, 30 March. https://www.bbc.com/news/world-us-canada-47762091

BBC News. 2017. Jeremy Corbyn Attacks Bosses over "Gig Economy". BBC News, 12 September. https://www.bbc.com/news/uk-politics-41233450

Blanc, Eric. 2019. Why Kautsky Was Right and Why You Should Care. Jacobin, 2 April. https://jacobinmag.com/2019/04/karl-kautsky-democratic-socialism-elections-rupture

Blackburn, Robin. 2018. The Corbyn Project: Public Capital and Labour's New Deal. New Left Review 111: 5-32

Bolton, Mark and Harry Pitt. 2018. Corbynism: A Critical Analysis. Dublin: Emerald.

Bratton, Benjamin. 2019. The Terraforming. New York: Stelka.

Bria, Francesca. 2018. A New Deal for Data. In Economics for the Many, edited by John McDonnell, Loc. 2694-2839. London: Verso [Kindle edition].

Broder, David. 2019. The State We Need. Jacobin, 25 February. https://jacobinmag.com/2019/02/the-state-we-need

Bruenig, Matt. 2019a. Bernie Wants Power in Workers' Hands, Jacobin, 29 June. https://jacobinmag.com/2019/05/bernie-sanders-funds-socialism-shares-cooperatives

Bruenig, Matt. 2019b. Bernie Wants You to Own More of the Means of Production, Jacobin, 14 October. https://www.jacobinmag.com/2019/10/bernie-wants-you-to-own-more-of-themeans-of-production

Coldewey, Devin. 2019. Bernie Sanders Makes Reinstating Net Neutrality A Campaign Promise. TechCrunch, 30 July. https://techcrunch.com/2019/07/30/bernie-sanders-makesreinstating-net-neutrality-a-campaign-promise/

${ }^{3}$ I owe some of these reflections to remarks by James Woodcock, at a workshop on class composition, held at the Rosa Luxemburg Stiftung, Berlin, on March 6, 2018. 
Corbett, Jessica. 2019. Sanders Unveils Workplace Democracy Plan to Expand Labor Rights and Double Union Membership. Common Dreams, 21 August. https://www.commondreams.org/news/2019/08/21/sanders-unveils-workplace-democracy-plan-expandlabor-rights-and-double-union

Corbyn, Jeremy. 2017. Speech to Co-operative Party Conference. 14 October 2017.

Corbyn, Jeremy. 2016. The Digital Democracy Manifesto. The Bullet, 9 September. https://socialistproject.ca/2016/09/b1303

Davoli, Paolo, Letizia Rustichelli and Francesco Tacchini, eds. 2013. The Birth of Digital Populism: Crowd, Power and Postdemocracy in the Twenty First Century. London: Obsolete Capitalism.

Dayen, David. 2019. How to Think About Breaking up Big Tech. The Intercept, 1 April. https://theintercept.com/2019/04/01/elizabeth-warren-tech-regulation-2020/

Dean, Jodi. 2017. Not Him, Us and We Aren't Populists. Theory \& Event 28 (1): 38-44.

DeJohn, Sam. 2017. Beyond Protest: Examining the Decide Madrid Platform for Public Engagement. GovLab, 13 November. http://thegovlab.org/beyond-protest-examining-the-decide-madrid-platform-for-public-engagement/

Delclós, Carlos. 2015. Hope is a Promise: From the Indignados to the Rise of Podemos in Spain. New York: Zed Books.

Della Porta, Donatella, Joseba Fernández, Hara Kouki, and Lorenzo Mosca. 2017. Movement Parties Against Austerity. Cambridge: Polity Press.

Die Linke. 2011. Programme of the DIE LINKE Party. https://www.die-linke.de/fileadmin/download/grundsatzdokumente/programm englisch/englisch die linke programm erfurt.pdf

Durand, Catherine and Corine Goldberger. 2018. Jean-Luc Mélenchon: The Uberization of Work is the Number One Enemy of Women [in French]. Marie-Claire, May 2018, https://www.marieclaire.fr/jean-luc-melenchon-I-uberisation-du-travail-est-I-ennemi-numero-un-des-femmes,849664.asp

Dyer-Witheford, Nick, Atle Kjosen, and James Steinhoff. 2019. Inhuman Power: Artificial Intelligence and the Future of Capitalism. London: Pluto.

Earle, James. 2018. The Corbyn Generation. Jacobin, 19 January. https://www.jacobinmag.com/2018/01/student-revolt-austerity-uk-corbyn-momentum

Feelthebern.org. 2019. Bernie Sanders On Privacy \& Digital Rights. https://feelthebern.org/bernie-sanders-on-privacy-and-digital-rights/

Feilner, Markus. 2009. Open Source im Wahlkampf - Teil 2: Mark Seibert Die Linke. Linux, September 2009. https://www.linux-magazin.de/ausgaben/2009/09/open-source-imwahlkampf-teil-2-mark-seibert-die-linke/

Fildes, Nic and Jim Pickard. 2019. Holding the Line: Labour’s £20bn Plan for Free Broadband. Financial Times, 15 November. https://www.ft.com/content/945d0a08-07a9-11ea9afa-d9e2401fa7ca

Foroohar, Rana. 2018. Techlash. Financial Times, 16 December. https://www.ft.com/content/76578fba-fca1-11e8-ac00-57a2a826423e

France Insoumise. 2017. Alternatives à l'ubérisation. Les livrets de la France Insoumise, http://pinguet.free.fr/ilmuberi.pdf

Gabbatt, Adam. 2015. Former Occupy Wall Street Protesters Rally Around Bernie Sanders Campaign. The Guardian, 17 September. https://www.theguardian.com/usnews/2015/sep/17/occupy-wall-street-protesters-bernie-sanders

Gerbaudo, Paul. 2018. The Digital Party. London: Pluto.

Gowan, Peter. 2019. A Plan to Win Socialism In America. Jacobin, 25 February. https://jacobinmag.com/2019/02/a-plan-to-win-socialism-in-america

Gowan, Peter and Mio Tastas Viktorsson. 2017, Revisiting the Meidner Plan. Jacobin, $22 \mathrm{Au}-$ gust. https://www.jacobinmag.com/2017/08/sweden-social-democracy-meidner-plan-capi$\underline{\text { tal }}$ 
Gray, Paul Christopher, ed. 2018. From the Streets to the State: Changing the World by Taking Power. New York: SUNY.

Greenfield, Adam. 2017. Radical Technologies: The Design of Everyday Life. New York: Verso.

Hamburger, Jacob. 2018. Whose Populism? The Mixed Messages of La France Insoumise. Dissent, Summer 2018, https://www.dissentmagazine.org/article/whose-populism-mixedmessages-france-insoumise-melenchon-left

Heater, Brian. 2018. Bernie Sanders Intros "Stop Bad Employers by Zeroing Out Subsidies BEZOS” Bill. TechCrunch, 16 September. https://techcrunch.com/2018/09/05/berniesanders-intros-stop-bad-employers-by-zeroing-out-subsidies-bezos-bill/

Holloway, John. 2002. Change the World Without Taking Power: The Meaning of Revolution Today. London: Pluto.

Jones, Sam. 2018. Spanish Artist Decries Censorship After Work Dropped From Art Fair. The Guardian, 22 February. https://www.theguardian.com/world/2018/feb/22/madridmayor-boycotts-arco-art-fair-opening-censorship-row-political-prisoners

Judis, John B. 2016. The Populist Explosion: How the Great Recession Transformed American and European Politics. New York: Columbia Global Reports.

Kaltwasser, Cristóbal Rovira, Paul Taggart, Paulina Ochoa Espejo, and Pierre Ostiguy, eds. 2017. The Oxford Handbook of Populism. Oxford: Oxford University Press.

Kipping, Katja, Julia Schramm, Anke Domscheit-Berg, Petra Sitte, and Martin Delius. 2017. 10 Points for a Digital Agenda of the LEFT. https//digitallinke.de

Kowalsky. Wolfgang. 2016. Time to Turn the Page of Platform Capitalism? Social Europe, 28 November. https://www.socialeurope.eu/time-turn-page-platform-capitalism

La France Insoumise (LFI). 2017. Alternatives à l'Ubérisation. L'Avenir en commun, 25 January. https://avenirencommun.fr/livrets-thematiques/le-livret-uberisation/

Labour Party. 2017. Alternative Models of Ownership: Report to the Shadow Chancellor of the Exchequer and Shadow Secretary of State for Business, Energy and Industrial Strategy. Labour.org.uk. https://labour.org.uk/wp-content/uploads/2017/10/Alternative-Modelsof-Ownership.pdf

Labour Party. 2019. It's Time For Real Change: The Labour Party Manifesto 2019. https://labour.org.uk/wp-content/uploads/2019/11/Real-Change-Labour-Manifesto-2019.pdf

Laclau, Ernesto and Chantal Mouffe. 1985. Hegemony and Socialist Strategy: Towards a Radical Democratic Politics. London: Verso.

Lawrence, Mathew, Andrew Pendleton, and Sara Mahmoud. 2017. Co-operatives Unleashed: Doubling the Size of the UK's Co-Operative Sector. London: New Economics Foundation.

Lima, Cristiano. 2019. Sanders Backs Calls to Break Up Facebook. Politico, 15 May. https://www.politico.com/story/2019/05/15/sanders-backs-calls-to-break-up-facebook1327881

López, Alejandro. 2019. Podemos, Catalan Nationalists Cover Up Role of Intelligence in Barcelona Attack. World Socialist Web Site, 23 July. https://www.wsws.org/en/articles/2019/07/22/pode-j22.html

López-Terra, Federico. 2017. Spain's Freedom of Speech Repression Is No Joke. The Independent, 19 April. https://www.independent.co.uk/news/science/spain-s-freedom-ofspeech-repression-is-no-joke-a7688341.html

Lunden, Ingrid. 2018. UK Labour Leader Jeremy Corbyn proposes a publicly-funded alternative to Facebook. Tech Crunch, 23 August. https://techcrunch.com/2018/08/23/uk-labourleader-jeremy-corbyn-proposes-a-publicly-funded-alternative-to-facebook/

Lutz, Eric. 2019. Bernie Sanders is Creeped Out By Amazon's Spy Tech, Too. Vanity Fair, 20 August 2019, https://www.vanityfair.com/news/2019/08/bernie-sanders-ban-amazonfacial-recognition-technology

Lüthje, Boy. 1993. On the Political Economy of 'Post-Fordist' Telecommunications: The US Experience. Capital and Class 17 (3): 81-117. 
Mason, Paul. 2015. Postcapitalism: A Guide to Our Future. New York: Allen Lane.

McDonnell, John, ed. 2018. Economics for the Many. London: Verso.

Mélenchon, Jean-Luc. 2017. L'ubérisation de la société. YouTube, 8 February. https://www.youtube.com/watch?v=TdP E6X7EMo

Morozov, Evgeny. 2016. Data Populists Must Seize Our Information - For the Benefit Of Us All. The Guardian, 4 December. https://www.theguardian.com/commentisfree/2016/dec/04/data-populists-must-seize-information-for-benefit-of-all-evgeny-morozov.

Morozov, Evgeny and Francisca Bria. 2018. Rethinking the Smart City: Democratizing Urban Technology. New York: Rosa Luxemburg Stiftung.

Mouffe, Chantal. 2018. For a Left Populism. New York: Verso.

Nikandrov, Niki. 2015. Spain: Podemos Party in the Crosshairs of US Intelligence Agencies", 3 June. https://www.strategic-culture.org/news/2015/06/20/spain-podemos-party-crosshairs-us-intelligence-agencies/

Offerman, Adrian. 2017. Open Source Pivotal in Digital Agenda of German Party The Left. Open Source Observatory, 8 August. https://joinup.ec.europa.eu

Orsini, Alexis. 2017. Le programme de Jean-Luc Mélenchon sur le numérique: 10 propositions clés à retenir Société, 6 February. https://www.numerama.com/politique/224878-numerique-et-tech-les-7-propositions-cle-de-jean-luc-melenchon.html

Rancière, Jacques. 2013. The People Are Not a Brutal and Ignorant Mass. Verso Blog, 30 January. https://www.versobooks.com/blogs/1226-the-people-are-not-a-brutal-and-ignorant-mass-jacques-ranciere-on-populism

Revelli, Marco. 2019. The New Populism: Democracy Stares into the Abyss. New York: Verso.

Sanders, Bernie. 2016. Our Revolution: A Future to Believe In. New York: St Martin's Press.

Scholz, Trebor and Nathan Schneider, eds. 2017. Ours to Hack and to Own: The Rise of Platform Cooperativism, A New Vision for the Future of Work and a Fairer Internet. New York: OR Press.

Scola, Nancy and Margaret McGill. 2019. Inside the Media Industry's Struggle to Take on Silicon Valley. Politico, 30 August. https://www.politico.com/story/2019/08/30/media-socialmedia-europe-1657902

Srnicek, Nick 2017. Platform Capitalism. Cambridge: Polity Press.

Srnicek, Nick and Alex Williams. 2015. Inventing the Future: Postcapitalism and a World Without Work. London: Verso.

Stevis-Gridneff, Matina. 2019. E.U.'s New Digital Czar: "Most Powerful Regulator of Big Tech on the Planet". New York Times, 10 September. https://www.nytimes.com/2019/09/10/world/europe/margrethe-vestager-european-union-tech-regulation.html

Stewart, Emily. 2019. We Are Still the 99\%". Vox, 30 April. https://www.vox.com/the-highlight/2019/4/23/18284303/occupy-wall-street-bernie-sanders-dsa-socialism

Sunkara, Bhaskar. 2019. The Exercise of Power. Jacobin, 25 February. https://jacobinmag.com/2019/02/the-exercise-of-power

The Economist. 2019a. Silicon Valley and the State Gird for War. The Economist, 3 October. https://www.economist.com/business/2019/10/03/silicon-valley-and-the-state-gird-for-war

The Economist. 2019b. Millennial Socialism. The Economist, 14 February. https://www.economist.com/leaders/2019/02/14/millennial-socialism

Van Dorn, Niels. 2017. The Parameters of Platform Capitalism. Krisis 2: 104-107.

Warren, Elizabeth. 2019. Here's How We Can Break Up Big Tech. Medium, 8 March. https://medium.com/@teamwarren/heres-how-we-can-break-up-big-tech-9ad9e0da324c

Watkins, Susan. 2016. Oppositions. New Left Review 98: 5-30.

Watson, Tom. 2019. Tom Watson Speech on Fixing the Distorted Digital Market. Labour.org.uk. https://labour.org.uk/press/tom-watson-speech-fixing-distorted-digital-market/ 
Williams, Alex and Nick Srnicek. 2013. \#ACCELERATE MANIFESTO for an Accelerationist Politics. Critical Legal Thinking Blog, 14 May. http://criticallegalthinking.com/2013/05/14/accelerate-manifesto-for-an-accelerationist-politics

\section{About the Author}

Nick Dyer-Witheford

Nick Dyer-Witheford, an Associate Professor in the Faculty of Information and Media Studies at the University of Western Ontario, is the author of Cyber-Marx: Cycles and Circuits of Struggle in High Technology Capitalism (Chicago: University of Illinois, 1999) and Cyber-Proletariat: Global Labour in the Digital Vortex (London: Pluto Press, 2015), and has also written on the video and computer game industry, the uses of the Internet by social movements and theories of technology. Two recent books are co-authorships: with Svitlana Matviyenko, Cyberwar and Revolution: Digital Subterfuge in Global Capitalism (University of Minnesota Press 2019), and with Atle Mikkola Kjøsen and James Steinhoff, Inhuman Power: Artificial Intelligence and the Future of Capitalism (Pluto Press 2019). 